Evolution of Sickness and Healing 



\section{Evolution of Sickness and Healing}

Horacio Fábrega, Jr. 
University of California Press

Berkeley and Los Angeles, California

University of Califomia Press

London, England

Copyright $\odot 1997$ by

The Regents of the University of California

First Paperback Printing 1999

Library of Congress Cataloging-in-Publication Data

Fábrega, Jr., Horacio

Evolution of sickness and healing / Horacio Fábrega, Jr.

p. $\mathrm{cm}$.

Includes bibliographical references and index.

ISBN 0-520-21953-8 (pbk. : alk. paper)

1. Social medicine. 2. Medical anthropology. 3. SickPsychology. 4. Human evolution. I. Title.

RA418.F323 1997

$306.4^{\prime} 61-\mathrm{dc} 20$

Printed in the United States of America

123456789

The paper used in this publication is both acid-free and totally chlorine-free (TCF). It meets the minimum requirements of American Standard for Information Sciences-Permanence of Paper for Printed Library Materials, ANSI Z39.48-1984. @ 
This is for Andrea Melanie and Michele Marie, with deep appreciation and gratitude to Joan Rome 
